\title{
Experimental Study on Propulsion Characteristic of Autonomous Intervention ROV
}

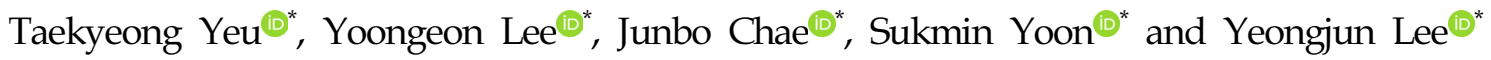 \\ "Marine ICT Research Division, Korea Research Institute of Ships and Ocean Engineering(KRISO), Daejeon, Korea
}

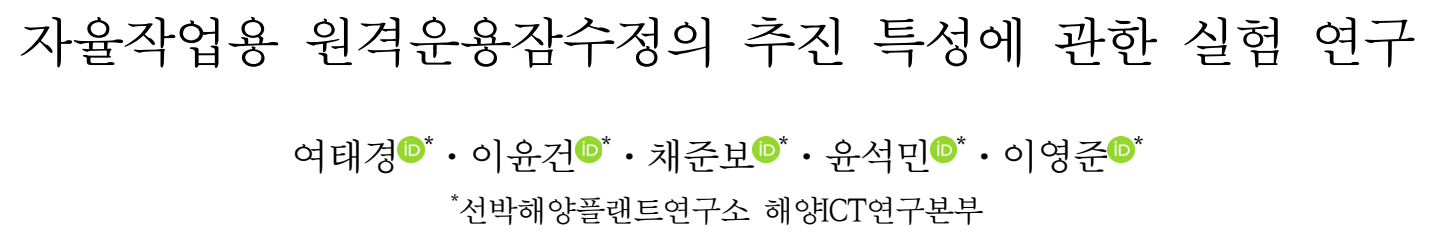

KEY WORDS: Remotely operated vehicle(ROV) 원격운용잠수정, Autonomous intervention 자율작업, Thrusting force 추력, Propulsion force 추진력, Underwater manipulator 수중로봇팔

\begin{abstract}
In autonomous interventions using an underwater vehicle with a manipulator, grasping based on target detection and recognition is one of the core technologies. To complete an autonomous grasping task, the vehicle body approaches the target closely and then holds it through operating the end-effector of the manipulator, while the vehicle maintains its position and attitude without unstable motion. For vehicle motion control, it is very important to identify the hydrodynamic parameters of the underwater vehicle, including the propulsion force. This study examined the propulsion characteristics of the autonomous intervention ROV developed by KRISO, because there is a difference between the real exerted force and the expected force. First, the mapping between the input signal and thrusting force for each underwater thruster was obtained through a water tank experiment. Next, the real propulsion forces and moments of the ROV exerted by thrusting forces were directly measured using an F/T (force/torque) sensor attached to the ROV. Finally, the differences between the measured and expected values were confirmed.
\end{abstract}

\section{1. 서 론}

오늘날 상당수의 수중작업(수중구난, 해양과학탐사, 해저유전 개발 등)에 무인수중잠수정(Unmanned underwater vehicle, UUV) 이 지속적으로 사용되어오고 있으며, 이들 작업은 수중에서의 조작(Manipulation) 기능까지 요구한다. 수중작업에서 가장 일반 적으로 사용되고 있는 ROV(Remotely operated vehicle)는 수상의 선박에 탑승한 2 명 이상의 숙련된 운용자에 의해 조종된다. 이 중 한명은 ROV 몸체를, 나머지 한명은 로봇팔을 각각 전담한다. $\mathrm{ROV}$ 는 선상의 갑판 위에 진 · 회수장치 및 전력공급장치, DPS (Dynamic positioning system) 등을 갖춘 전문 지원 선박과 숙련된 전문 인력이 요구되므로 많은 유지비용이 필요로 하며, 운전자 의 숙련도, 작업시간에 따른 피로누적 정도, 그리고 지원 선박-잠 수정 사이의 물리적 거리로 인한 시간 지연(Time delay) 등에 의 해 작업 효율이 좌우되는 문제점이 있다(Haugalokken et al.,
2018). 이러한 문제점들을 극복하기 위해, 자율수중잠수정 (Autonomous underwater vehicle, $\mathrm{AUV}$ )에 로봇팔을 장착시켜 작 업을 수행하는, I-AUV(Intervention AUV) 또는 UVMS(Underwater vehicle manipulator system)에 대한 연구가 1990년부터 진행되어 왔다(Mohan and Kim, 2015; Simetti et al., 2018). AUV는 ROV에 비해 상대적으로 중량이 가볍고, 사람의 개입과 케이블로부터 자유로우며, 소형 선박으로 진 - 회수가 가능하여 운용비용을 줄 일 수 있어 현재 많은 연구가 진행되고 있다.

선박해양플랜트연구소(Korea Research Institute of Ships \& Ocean Engineering, KRISO)에서는 2017년부터 수중잠수정을 활 용한 자율작업에 필요한 핵심 알고리즘 개발 연구에 착수했으며, 이를 위한 자율작업용 원격운용잠수정(Autonomous intervention $\mathrm{ROV}, \mathrm{AI}-\mathrm{ROV}$ ) 플랫폼을 개발하였다(Fig. 1). AI-ROV는 육상으 로부터 케이블을 통해 전력과 통신을 공급받으며, 7축의 전기식 로봇팔을 탑재하고 있다. AUV 보다 ROV를 활용하는 이유는 지

Received 30 July 2019, revised 16 September 2019, accepted 16 October 2019

Corresponding author Yeongjun Lee: +82-42-866-3864, leeyeongjun@kriso.re.kr ORCID: https://orcid.org/0000-0002-3808-8349 It is a recommended paper from the proceedings of 2019 spring symposium of the Korea Marine Robot Technology (KMRTS) which is one of the divisions belong to the Korean Society of Ocean Engineers (KSOE).

(C) 2019, The Korean Society of Ocean Engineers

This is an open access article distributed under the terms of the creative commons attribution non-commercial license (http://creativecommons.org/licenses/by-nc/3.0) which permits unrestricted non-commercial use, distribution, and reproduction in any medium, provided the original work is properly cited. 


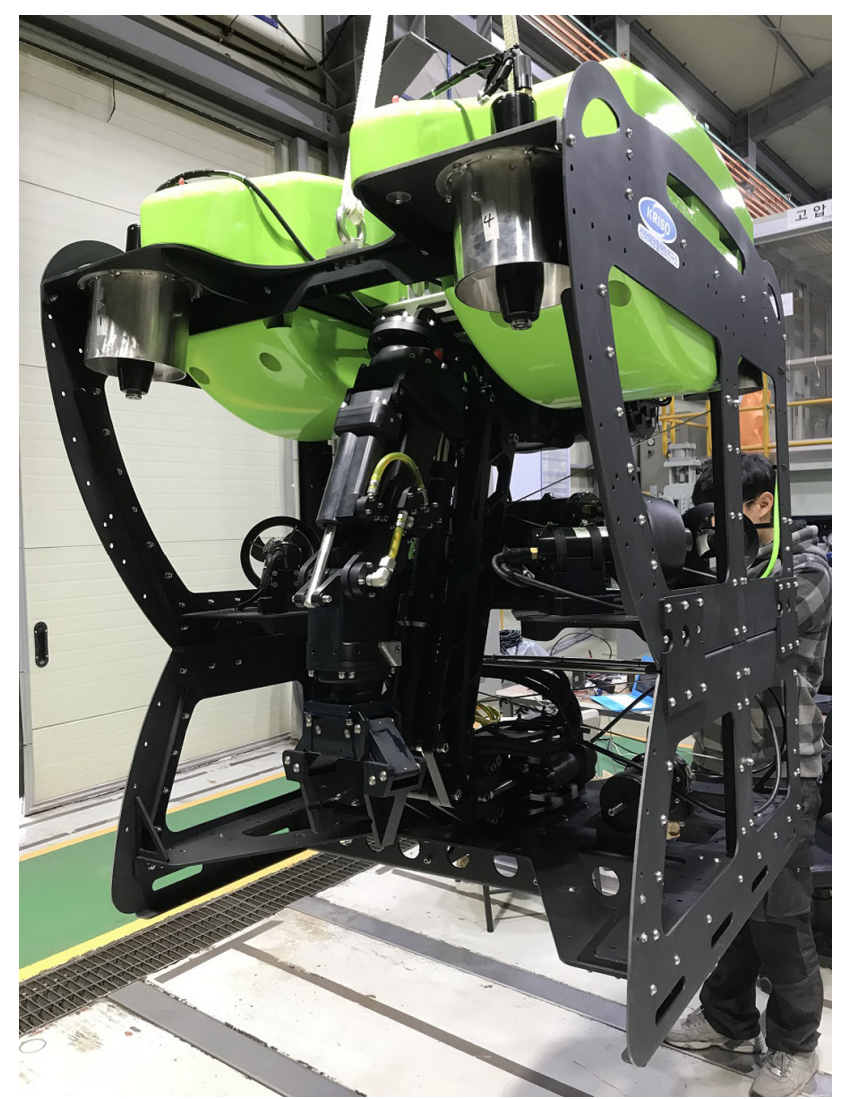

Fig. 1 KRISO AI-ROV

속적인 전력공급과 통신이 가능하므로, 알고리즘 개발과정에서 의 확인 및 검증에 유리한 장점을 지니고 있기 때문이다. 수중로 봇팔(Underwater manipulator)은 ECA Group 사의 7E-MINI 모델을 채택하였으며, 이것의 기중 중량은 $51 \mathrm{~kg}$ (수중 $30 \mathrm{~kg}$ ), 최대 길이는 약 $1.4 \mathrm{~m}$ 이다. ROV의 수중 위치, 속도, 자세 등을 계측하기 위하 여 관성측정장치(Inertial measurement unit, IMU), 도플러 속도계 (Doppler velocity log, DVL), 수심(Depth) 센서 등이 탑재되어 있 으며, 4 개의 수평추진기와 4 개의 수직추진기를 통해 6축 운동을 제어한다(Yeu et al., 2019).

일반적으로 수중잠수정을 활용한 자율작업에 있어, 잠수정이 수중 대상물체와 위치를 정확하게 인식하여 작업 반경 내에 잠 수정 몸체를 접근시킨 후, 로봇팔을 이용하여 물체를 파지하는 것이 기본적 핵심 기술이다. 이를 위해 잠수정 몸체는 대상물체 까지 스스로 경로를 생성하며 움직여야 하고, 파지를 위해 로봇 팔이 대상체로 접근할 때 몸체가 흔들리지 않도록 자세를 유지 하는 등의 제어 기술이 요구된다.

대부분의 수중잠수정은 프로펠러(Propeller) 형식의 추진기 (Thruster)를 사용하고 있으며, 자세 및 운동 제어를 위해서는 동적 특성과 함께 추진기 특성을 정확하게 파악하는 것이 중요하다.

일반적으로 추진기 동역학(Thruster dynamics) 모델은 크게 전 기 모터 모델과 프로펠러 모델을 포함한 유체역학 모델로 구성 되며, 유체역학 모델은 차원 해석(Dimensional analysis)을 통해 얻어진 정상상태 방정식(Steady-state equation) 또는 준정상상태 방정식(Quasi-steady-state equation)으로 표현되고 있다(Ait-Ahmed et al., 2007). 이것은 무차원 항(Non-dimensional term)인 진행비
(Advance ratio)의 함수로 표현되며, 프로펠러의 직경(Diameter), 회전속도(Rotation velocity), 프로펠러의 이동 속도가 주요 인자 이다. 이에 대하여 지금까지 많은 연구가 진행되어 왔으며 (Yoerger et al., 1990; Fossen T.I., 1994; Healey et al., 1995; Tsukamoto et al., 1997), 프로펠러 회전속도와 프로펠러에 의해 발생된 유체 속도 성분으로 표현되는 일반화 방정식이 널리 사 용되고 있다. 그러나 추진기 성능은 실제 동작하는 환경 조건에 많은 영향을 받기 때문에 모델과 실제 출력 사이의 오차는 항상 존재한다. 이러한 문제를 해결하기 위해, 추진기 지령 입력과 추 력 사이의 관계 함수를 직접 측정하는 방법도 제안되어 왔다.

본 연구에서는 수조 실험을 통해 $\mathrm{AI}-\mathrm{ROV}$ 에 장착된 추진기 추력(Thrusting force) 및 ROV 추진력(Propulsion force) 특성을 정확하게 파악하고자 한다. 먼저, 1축 로드셀(Load-cell)이 장착 된 추력 측정 장치를 활용한 수조 실험을 통해, 각 추진기별 특 성, 즉 입력-추력 관계식을 얻는다. 다음으로는 8 개의 추진기를 로봇에 장착시킨 후, 6축 F/T(Forec/Torque)센서를 이용하여 추 진기 작동에 따라 발생되는 추진력과 모멘트를 측정하는 실험 을 수행한다. 본 실험 결과로부터 각 개별 추진기 출력 합산에 의한 이론적 추진력과 $\mathrm{F} / \mathrm{T}$ 센서로 부터 실측된 추진력과의 비교 를 통해, $\mathrm{ROV}$ 의 추진력 감쇄를 정확히 확인하고자 한다.

\section{ROV 플랫폼 개발}

수중잠수정을 활용한 자율작업에 요구되는 핵심기술 개발을 위해, 선박해양플랜트연구소에서는 AI-ROV 플랫폼을 개발하였 다. AI-ROV는 크게 몸체부와 로봇팔부로 구성되며, 로봇팔부를 분리시키면 일반 조사 목적의 ROV 형태를 갖는다.

\subsection{ROV 플랫폼 사양}

$\mathrm{ROV}$ 몸체부는 알루미늄 몸체 프레임, 4개의 수평추진기, 4개 의 수직추진기, 4 개의 부력재 블록, ROV 제어용 내압용기 (Housing for ROV control) 및 이미지 처리용 내압용기(Housing for image processing) 외에, IMU, DVL, 수심 센서, 4대의 수중 카메라, 2개의 LED(Light emitting diode) 라이트(Light), 수중레이 저스캐너 등으로 구성된다. 로봇팔부는 7축의 전기식 수중로봇 팔과 함께, 압력보상기, 압력보상용 매니폴더 블럭(Mainfold block), 로봇팔 제어용 내압용기(Housing for manipulator control), 그리고 하부 프레임으로 구성된다. ROV 플랫폼의 크기는 너비 $920 \mathrm{~mm}$, 깊이 $1,100 \mathrm{~mm}$, 높이 $1,200 \mathrm{~mm}$ 이며, 기중 중량은 약 $206 \mathrm{~kg}$ 이다. 로봇팔 중량은 $51 \mathrm{~kg}$ (수중 $30 \mathrm{~kg}$ )이며, 최대 길이는 약

Table 1 Specifications of autonomous intervention ROV

\begin{tabular}{cc}
\hline \hline Items & Value \\
\hline Mass & $206.1 \mathrm{~kg}$ \\
Length $(L)$ & $1,100 \mathrm{~mm}$ \\
Height $(H)$ & $1,266 \mathrm{~mm}$ \\
Width & $924 \mathrm{~mm}$ \\
COG (Center of gravity) $(Z)$ & $721.7 \mathrm{~mm}$ \\
COB (Center of buoyancy) $(Z)$ & $933.3 \mathrm{~mm}$ \\
\hline
\end{tabular}


$1,400 \mathrm{~mm}$ 이다. $\mathrm{ROV}$ 전체 중량 및 부력, 그리고 중심 위치 정보 등은 몸체 프레임과 각종 센서를 비롯한 모든 부품들의 기중 및 수중 중량을 실측한 후, 이들 정보를 $\mathrm{CAD}$ (Computer-aided design)에 반영함으로써 Table 1과 같은 사양을 얻었다.

\section{2 추진기 사양}

$\mathrm{AI}-\mathrm{ROV}$ 에 장착되어 있는 수평추진기는 $\mathrm{Tecnadyne}^{\mathrm{TM}}$ 사의 Model 561 로서, 정격 전력은 $300 \mathrm{VDC}, 1 \mathrm{KW}$ 이다. 수직추진기는 동일사 제품의 Model 541 로서 $300 \mathrm{VDC}, 500 \mathrm{~W}$ 이며, 정·역 출력 이 거의 동일하다. 두 추진기는 RS485 시리얼 통신 방식을 통해 신호를 전송하며, PWM(Pulse width modulation) 값(범위: 0 255) 에 의해 속도(RPM) 제어가 구현된다. 각 추진기의 상세 사양은 Table 2와 같다.

Table 2 Specifications of horizontal and vertical thrusters

\begin{tabular}{ccccc}
\hline Model & $\begin{array}{c}\text { Force [N] } \\
\text { Forward / } \\
\text { Inverse }\end{array}$ & $\begin{array}{c}\text { Power [W] / } \\
\text { Voltage [V] }\end{array}$ & $\begin{array}{c}\text { Size [mm] } \\
\text { Dia. / Length }\end{array}$ & $\begin{array}{c}\text { Communi } \\
\text { cation }\end{array}$ \\
\hline & & & & \\
& & & & \\
& & & & \\
\end{tabular}

\section{3 수중잠수정 운동방정식}

수중잠수정 운동방정식은 다음과 같이 일반적으로 표현된다 (Giovanni, 1998).

$$
M \dot{v}+C v+D_{L} v+D_{Q}|v| v+W=T
$$

여기서, $M$ 은 질량 및 부과질량, $C$ 는 코리올리 항, $D_{L}$ 은 선형 항력, $D_{Q}$ 는 비선형 항력, $W$ 은 중력과 부력의 합력인 복원력(Restoring force), 그리고 $T$ 는 추진기에 의해 발생되는 힘과 토오크(Torque)를 각각 나타내는 행렬이며, $v$ 는 잠수정의 속도를 의미한다.

비교적 낮은 속도로 움직이는 ROV의 경우는 일반적으로 코 리올리의 항을 무시할 수 있으므로, 식 (1)을 다음과 같이 간략 하게 표현할 수 있다.

$$
M \dot{v}+D_{L} v+D_{Q}|v| v+W=T
$$

수중에서의 로봇팔을 이용한 자율작업을 위해서는 ROV 자세 및 운동 제어가 매우 중요하며, 최적의 제어기 설계를 위해서는 식 (2)의 파라미터, $M, D_{L}, D_{Q}, W$ 정보가 중요하다.

일반적으로 $\mathrm{ROV}$ 의 경우, 상기 동특성 파라미터는 견인 (Towing) 실험, 진자(Pendulum) 실험, 탑재 센서(On-board sensor) 활용 실험 등을 통해 측정된 운동특성정보를 기반으로 하는 시 스템 예측(System identification) 방법이 널리 이용되고 있다. 견 인 실험과 진자 실험을 통한 예측 방법은 비교적 정확한 파라미
터 예측이 가능하다는 장점이 있지만, $\mathrm{ROV}$ 운동 관련 정보를 얻 기 위한 적정 사양과 규모의 실험 설비, 높은 실험 비용 등의 단 점이 있다. 반면, 탑재 센서 활용 실험은 $\mathrm{ROV}$ 에 장착된 센서의 정밀도에 의해 예측 성능이 크게 좌우되지만, 요구된 입력 패턴 에 따라 $\mathrm{ROV}$ 를 움직이고 운동 정보를 계측하는 과정이 비교적 빠르고 쉽게 진행될 수 있어 현재 널리 이용되고 있다. 센서 활 용 실험 방식에서는 탑재 센서 정밀도와 함께 ROV 몸체 운동을 발생시키는 추진기의 추력 정보가 중요한 파라미터가 된다.

\section{3. 추진기 입·출력 특성 실험}

일반적으로 추진기 동특성은 무차원 항인 진행비의 함수, 즉 프로펠러의 직경, 회전속도, 프로펠러의 이동 속도로 표현된다. 추진기 모델링 관련하여 지금까지 많은 연구가 진행되어 왔으며, 프로펠러 회전속도와 프로펠러에 의해 발생된 유체 속도 성분으 로 표현되는 일반화 방정식이 널리 사용되고 있다. 저속 운동 조 건에서는 일반화 방정식은 다음과 같이 간략하게 표현된다.

$$
T=a n|n|
$$

여기서, $a$ 는 상수(Constants), $n$ 은 프로펠러 회전속도를 의미한 다. 대부분 추진기의 실제 출력 특성은 유체의 비선형 특성에 의해 식 (3)과 다소 차이를 보이므로, 본 연구에서는 추진기에 의해 발생되는 힘의 성분, $T$ 에 대한 정보를 실험을 통해 정확 히 측정하고자 한다.

\section{1 추력 측정용 실험장치 구성}

수직추진기와 수평추진기의 입력 지령, $\mathrm{PWM}(\mathrm{Pulse}$ width

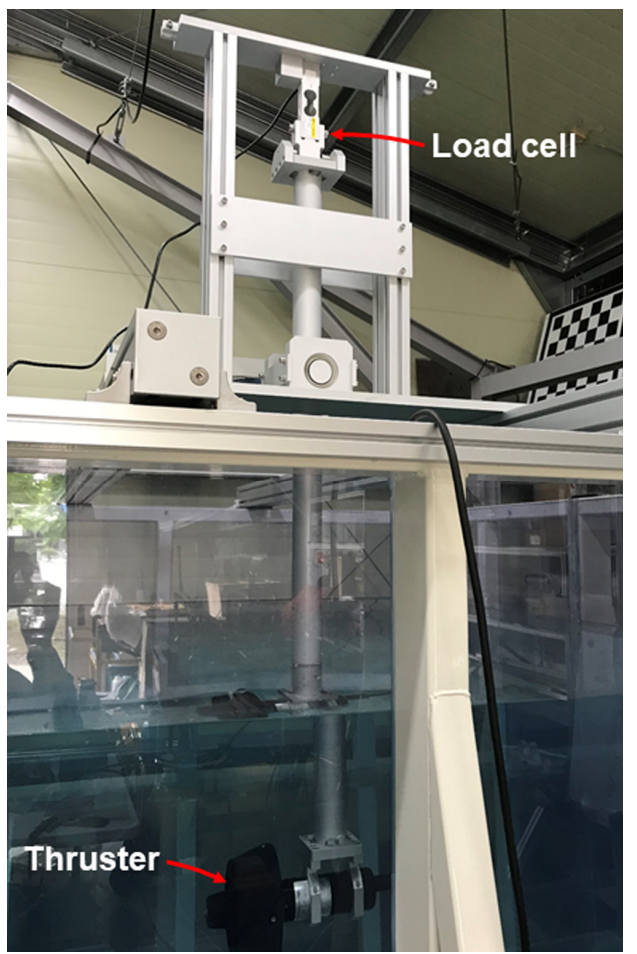

Fig. 2 Experimental equipment for measuring thrusting force 


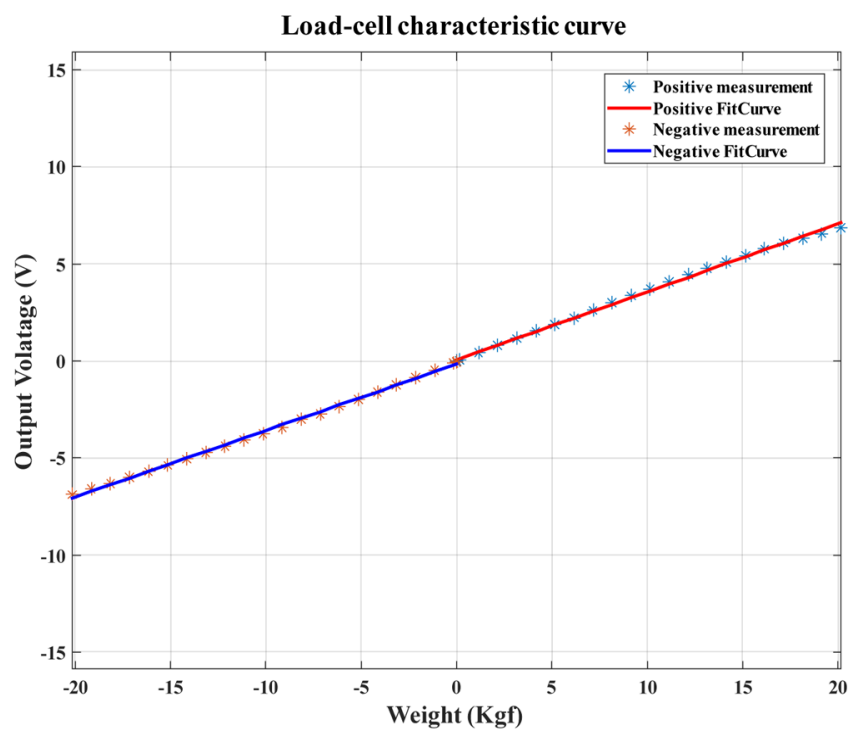

Fig. 3 Load-cell characteristic curve

modulation) 값에 대한 추진기 축 방향의 추력 정보를 얻기 위해, Fig. 2의 추력측정용 실험 장치를 제작하였다. 이것은 로드셀 고정 용 상부 프레임, 추진기 고정 및 힘 프레임, 그리고 측정 장비 고정 을 위한 중간판으로 구성된다. 추력 측정 원리는 수중에 설치된 추진기 프로펠러의 회전에 의해서 발생되는 축방향의 힘이 수직파 이프를 통해 상부에 고정된 로드셀로 전달되어 계측된다.

본 실험에서는 추력 측정 실험 전, 분동(Weight)을 이용하여 로드셀의 교정(Calibration) 실험을 우선적으로 수행하였으며, 로 드셀에서 측정된 전압과 중량사이의 특성은 Fig. 3 과 같다.

Fig. 3은 분동을 $0 \sim 20 \mathrm{~kg}$ 까지 $1 \mathrm{~kg}$ 씩 증가시키면서 로드셀로 부터 출력된 전압을 측정한 결과이다. 여기서, '*)은 실측된 데 이터이며, '실선'은 실측된 값으로부터 Matlab 프로그램의 Polyfit 함수를 이용하여 1차 방성식으로 근사화(Fitting)한 결과 이다.

\section{2 추진기 입·출력 특성 실험 결과}

추진기 추력 특성 실험은 모든 추진기를 대상으로 진행되었 으며, 입력 지령, PWM 값을 0 부터 220 까지 20 단위씩 증가시키 면서 발생되는 힘을 측정하였다(Fig. 4). PWM 값 220 부터 250 까지의 구간은 프로펠러 고속 회전으로 급격하게 발생된 유동 이 프로펠러로 유입되어 측정 오차를 발생시킨 점과 과도한 작 동에 따른 추진기 손상을 사전에 방지하기 위해 수행하지 않았 다. 실제 ROV 운용에 있어서도 추진기 보호를 위해 PWM 값을 220 까지로 제한하여 사용한다.

Fig. 4(a)는 수평추진기, Fig. 4(b)는 수직추진기의 입력 지령 (PWM)에 대하여 측정된 추력을 각각 나타내고 있다. 각 그래프 에서 'o'는 로드셀로부터 계측된 값, 그리고 '실선'은 실측된 값 으로부터 Matlab 프로그램의 Polyfit 함수를 이용하여 근사화한 결과를 각각 의미한다.

양의 PWM 값은 추진기의 정방향 회전, 음의 값은 역방향 회 전을 의미하며, 근사 오차를 최소화하기 위해 가로축을 3 개의 구간(-220 -50, -50 50, 50 220)으로 나누고, 각 구간별로 근사화 관계식을 얻었다. 이것은 정 - 역 방향의 서로 다른 특성과 추진

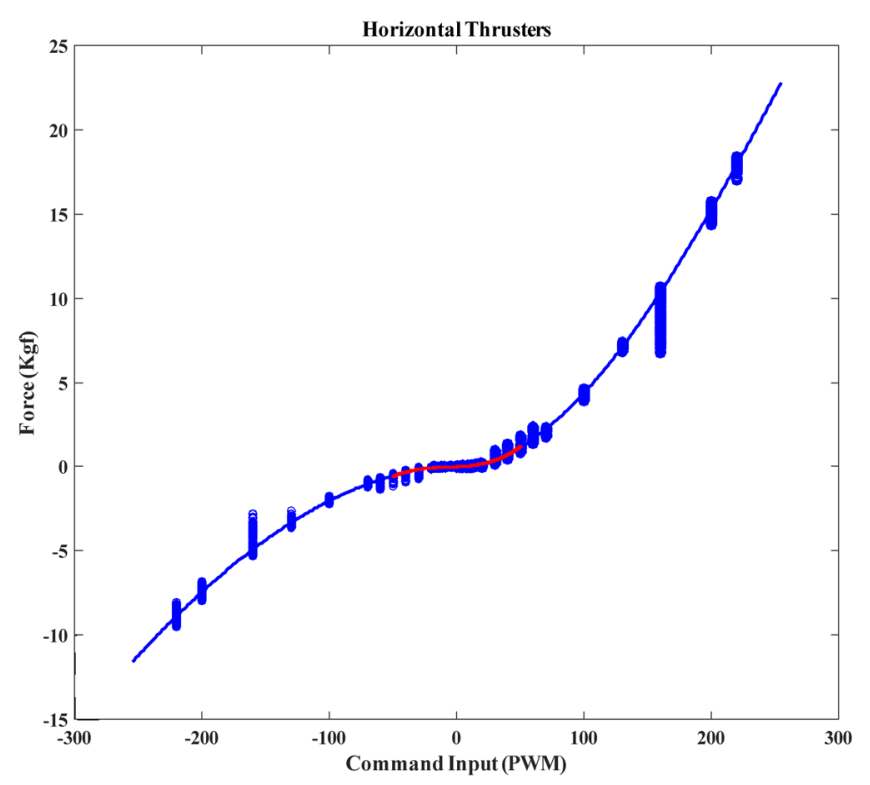

(a) Horizontal thruster

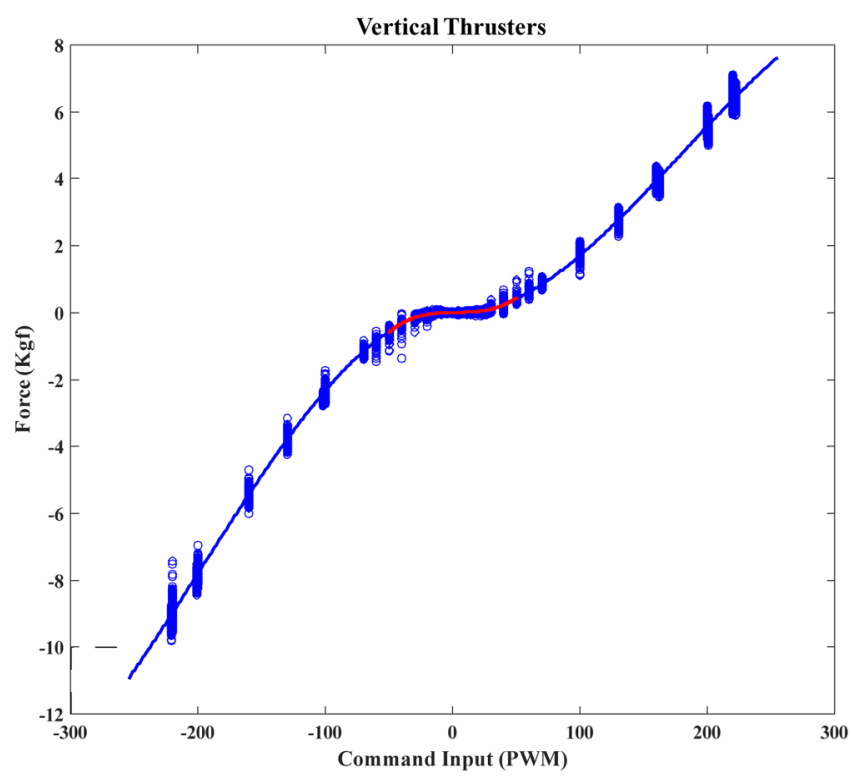

(b) Vertical thruster

Fig. 4 PWM-Thrusting force mapping

기 주요 특성 중 하나인 불감대(Dead zone), ‘붉은색 실선’을 정 밀하게 반영하기 위함이다.

수평추진기 및 수직추진기에 대한 각 구간별 근사화 관계식 은 식 (3)-(4)의 3차 함수 형태로 정의된다.

$$
\begin{gathered}
\tau_{i}^{H}=a_{1}^{H} P W M^{3}+a_{2}^{H} P W M^{2}+a_{3}^{H} P W M+a_{4}^{H} \\
\tau_{i}^{V}=a_{1}^{V} P W M^{3}+a_{2}^{V} P W M^{2}+a_{3}^{V} P W M+a_{4}^{V}
\end{gathered}
$$

여기서, $\tau$ 는 추진기 추력, 위첨자 $H$ 는 수평(Horizontal), $V$ 는 수 직(Vertical)을, $i$ 는 추진기 순서를 의미한다. 추진기 및 구간별 계수(Parameter)는 Table 3과 같다. 
Table 3 Parameters of PWM-Force equation

\begin{tabular}{cccccc}
\hline \hline Thruster & Section & $a_{1}$ & $a_{2}$ & $a_{3}$ & $a_{4}$ \\
\hline Horizontal & $-250 \sim-50$ & -0.000000 & -0.000200 & 0.001464 & 0.011160 \\
thruster & $-50 \sim 50$ & 0.000001 & 0.000122 & 0.003904 & -0.007121 \\
& $50 \sim 250$ & -0.000001 & 0.000495 & -0.000156 & -0.003075 \\
Vertical & $-250 \sim-50$ & -0.000001 & -0.000320 & -0.002786 & 0.016043 \\
thruster & $-50 \sim 50$ & 0.000004 & -0.000030 & 0.000807 & 0.004158 \\
& $50 \sim 250$ & -0.000000 & 0.000245 & -0.002962 & 0.009060 \\
\hline
\end{tabular}

\section{ROV 추진력 측정 실험}

일반적으로 수중잠수정은 추진기 배치에 의해 발생된 추력의 합력에 의해 추진력과 모멘트가 발생되며, 이것이 잠수정을 움 직인다. 이때 잠수정에 생성되는 추진력과 모멘트는 이론적으 로는 추진기 배치에 따른 추력의 합력과 동일해야 한다. 그러나 추진기와 잠수정 몸체, 추진기와 추진기 사이의 상호 영향, 추 진기와 잠수정 내부 장비와의 상호 간섭 등으로 인해 추력 손 실이 발생하며, 이것은 잠수정의 추진력 또는 모멘트 저하를 가 져오므로, 정확한 분석이 필요하다.

본 연구에서는 KRISO AI-ROV의 실질적 추진력과 손실 정도 를 정확히 확인하기 위해, 6축 $\mathrm{F} / \mathrm{T}$ 센서를 이용한 측정 실험을 수행하였다.

\section{1 추진기 배치}

KRISO AI-ROV의 추진기 배치는 Fig. 5와 같다. 수평 추진기 의 경우, 벡터 방식을 고려하여 $\mathrm{ROV}$ 전면 기준으로 $45^{\circ}$ 회전시 켜 고정되어 있으며, 이것은 수중작업에서 로봇팔 움직임에 따 른 위치 유지 및 경로 제어를 염두에 둔 것이다(Christ and Werinli, 2007). 수직추진기는 4개 모두 ROV 몸체 중심 방향으 로 $5^{\circ}$ 기우려 설치되었으며, 추진기 작동 시에 발생하는 상.하 방향의 유동 흐름을 원활하게 보장하기 위함과 로봇팔 움직임 에 따른 로봇 몸체의 롤(Roll) 및 피치(Pitch) 운동 보상을 위해 수직방향 추진력을 최대한 확보하기 위한 것이다.

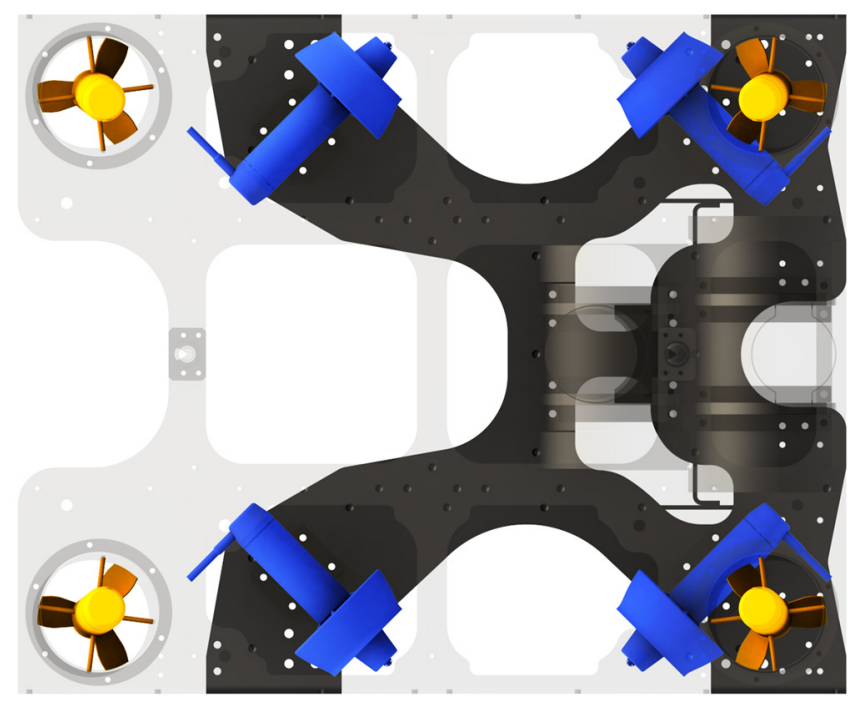

Fig. 5 Thruster allocation from top view
추진기 배치에 의해 발생되는 각 방향의 추진력과 모멘트, $T$ 는 식 (5)와 같이 얻어진다.

$$
T=B\left[\begin{array}{l}
\tau^{H} \\
\tau^{V}
\end{array}\right]
$$

여기서,

$$
B=\left[\begin{array}{cccccccc}
\cos \alpha-\cos \alpha-\cos \alpha & \cos \alpha & 0 & 0 & 0 & 0 \\
\sin \alpha & \sin \alpha & -\sin \alpha-\sin \alpha & 0 & 0 & 0 & 0 \\
0 & 0 & 0 & 0 & -\sin \beta & -\sin \beta & -\sin \beta & -\sin \beta \\
0 & 0 & 0 & 0 & -d_{1} \sin \beta & -d_{1} \sin \beta & d_{1} \sin \beta & d_{1} \sin \beta \\
0 & 0 & 0 & 0 & -d_{2} \sin \beta & d_{2} \sin \beta & d_{2} \sin \beta & -d_{2} \sin \beta \\
-d_{3} & d_{4} & -d_{4} & d_{3} & 0 & 0 & 0 & 0
\end{array}\right]
$$

$\alpha$ 는 수평추진기 회전각, $\beta$ 는 수직추진기 기울기를 의미하며, $d_{1}, d_{2}$ 는 ROV 중심점과 수직추진기 사이의 거리 $d_{3}, d_{4}$ 는 $\mathrm{ROV}$ 중심점과 수평추진기 사이의 거리를 각각 나타낸다.

\subsection{ROV 추진력 측정용 실험장치}

추진기 작동에 따른 ROV의 추진력과 모멘트를 측정하기 위 해, ATI사의 OMEGA-160 F/T센서를 Fig. 6과 같이 ROV 상부의 중앙에 설치하였다.

상기 측정 실험은 선박해양플랜트연구소의 토양 수조에서 수 행되었다. 수조의 크기는 폭 $6 \mathrm{~m}$, 길이 $25 \mathrm{~m}$, 깊이 $2.7 \mathrm{~m}$ 이며, 지 원 장비로는 대차(Carriage)가 구비되어 있다. 추진기 작동 시 움 직임을 구속시키는 것과 동시에 발생되는 힘과 모멘트를 정확 하게 측정하기 위하여, $\mathrm{ROV}$ 를 대차 하부 프레임에 알루미늄 파 이프를 이용하여 단단히 고정시킨다(Fig. 7).

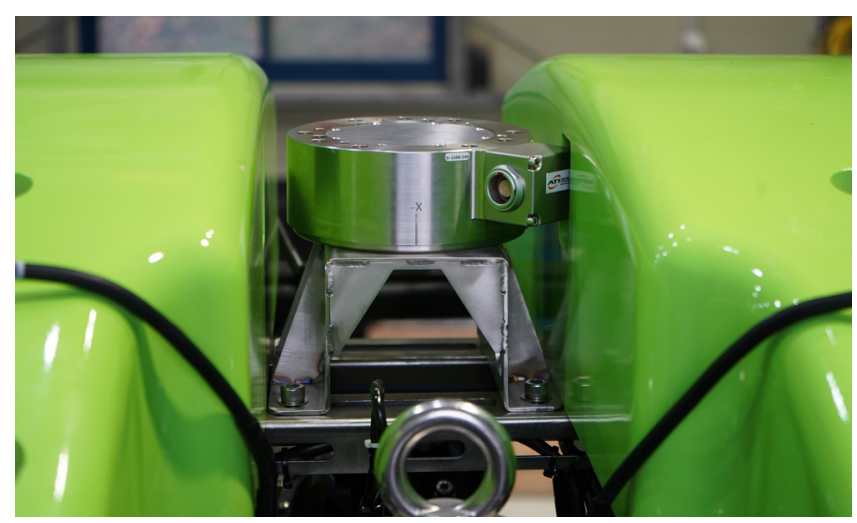

Fig. 6 F/T (Force/Torque) sensor fixed on ROV 


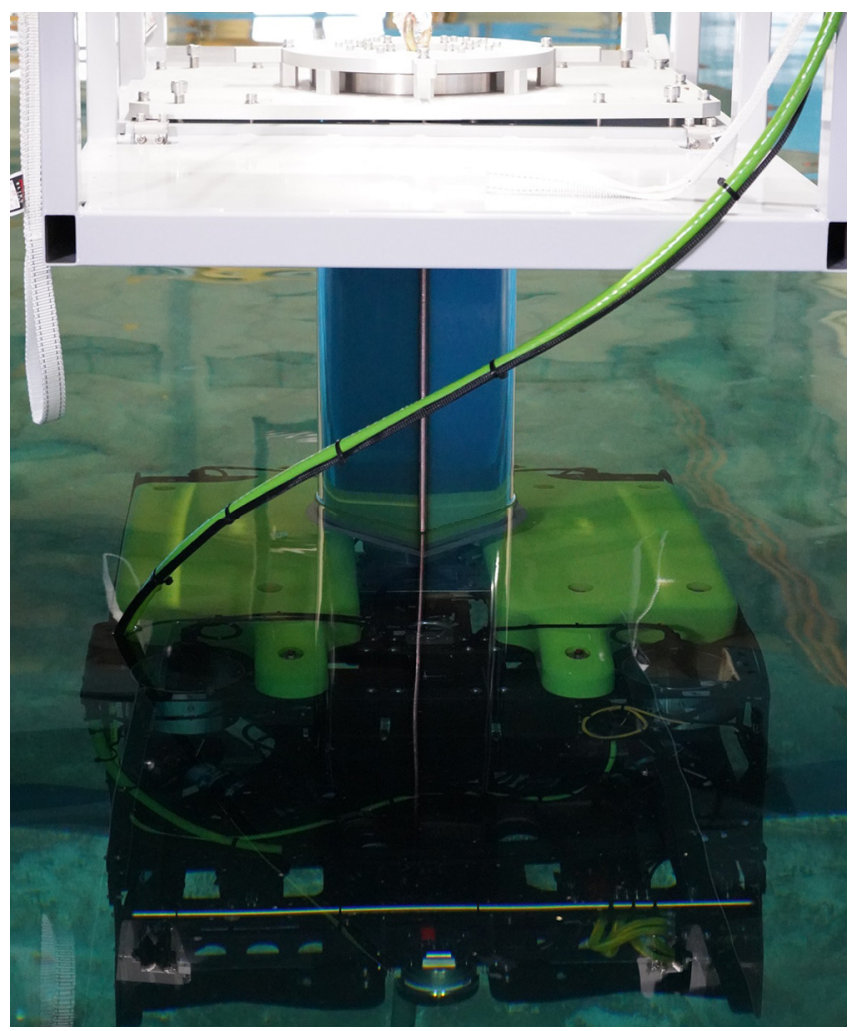

Fig. 7 Experimental facility for measuring propulsion forces and moments

\section{3 추진력 측정 결과}

본 측정 실험에서는, 6축에 대하여 각 축 방향으로만 힘 또는 모멘트가 지배적으로 발생하도록 입력값을 설정한다. Fig. 8은 $x$ 축(Surge) 방향으로만 추진력이 발생되도록 각 수평추진기에 지령된 PWM 값을 나타내고 있다. ROV 전방에 배치된 1 번과 4 번 수평추진기는 정방향 회전, 그리고 ROV 후방에 설치된 2번 과 3 번 수평추진기는 역방향 회전을 통해 전진 방향으로 추력 을 발생시킨다.

Fig. 9는 Fig. 8과 같이 적정하게 설정된 입력값을 통해 각 축 에 발생된 ROV의 추진력과 모멘트 크기를 보여준다. Fig. 9의 위에서부터 $x$ 축(Surge), $y$ 축(Sway), $z$ 축(Heave) 방향의 추진력, 그리고 $z$ 축 방향의 회전 모멘트를 각각 나타내며, 각 그래프에 서 '빨간색'실선은 입력지령에 따라 발생되는 추진기 추력의 합 력 성분의 값, '파란색'은 $\mathrm{F} / \mathrm{T}$ 센서를 통해 측정된 실제 추진력 또는 모멘트를 의미한다. 특히, 빨간색과 파란색 사이의 차이는 지령값 크기에 비례하여 점차 커지는 것을 확인할 수 있다. 추 력의 합력 성분 대비 실제 계측된 값은, $x$ 축 방향은 약 $24 \%, y$ 축 방향은 약 $29 \%, z$ 축 방향은 $19 \%, z$ 축 회전 성분은 약 $26 \%$ 의 감소가 발생했음을 확인할 수 있었다.

이와 같은 감소의 주요 원인은 추진기-추진기 사이에서 발생 된 유동의 상호 간섭과 추진기의 ROV 내부 고정으로 프레임 또는 내부 장치에 의한 유동 방해 등이다. 실험결과로부터 수평 추진기 작동에 의해 발생되는 $x$ 축, $y$ 축 방향의 추진력과 $z$ 축 방향의 모멘트 감소가 수직추진기 작동에 의한 $z$ 축 방향의 추 진력 감소 보다 큰 것을 알 수 있다. 이것은 수평추진기가 ROV
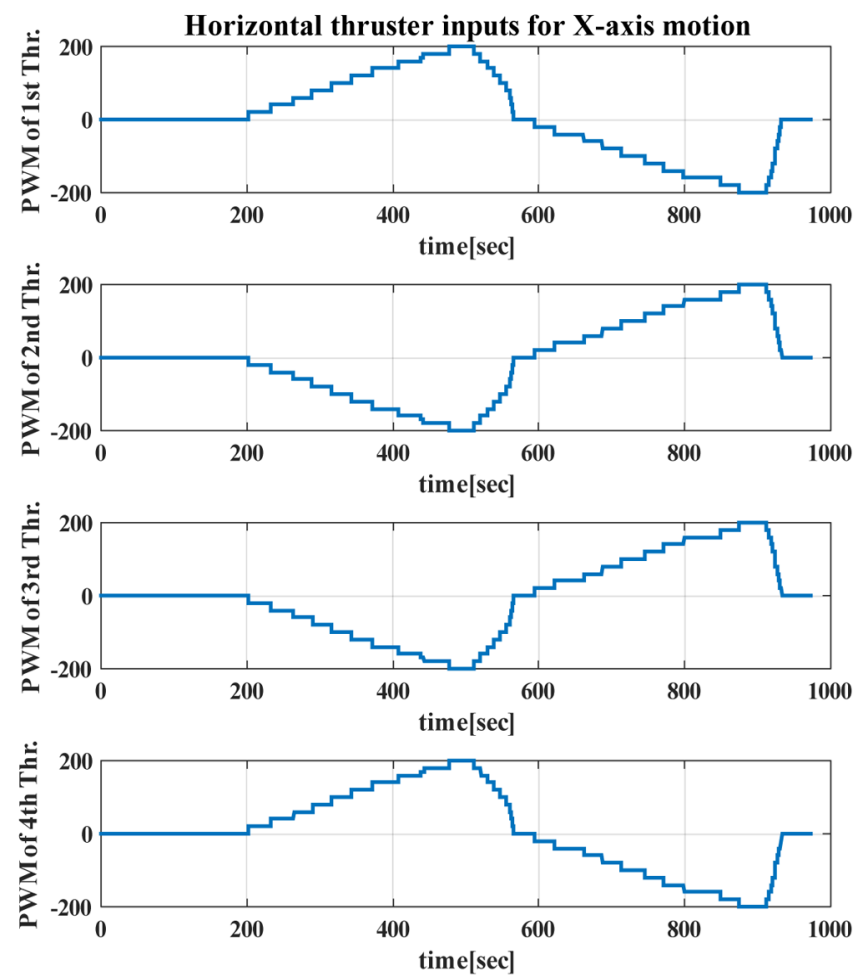

Fig. 8 Input commands in horizontal thrusters for surge ( $x$-axis) motion of ROV

몸체 내부에 설치되어 있어, 추진기-추진기 사이에서 발생된 유 동의 상호 영향과 $\mathrm{ROV}$ 프레임과 로봇팔 몸체에 의한 추진기 유동 방해로 인해 감소가 큰 것으로 분석된다. Fig. 9의 위에서 3 번째 그래프의 수평추진기의 경우는 음(-)의 추진력과 양 $(+)$ 의 추진력에서의 감소 크기가 다른 것을 확인할 수 있다. 즉, 음의 추진력 구간에서는 오차가 최대 $29 \%$ 까지 나타나지만, 양의 구 간에서는 $9 \%$ 정도로 작게 나타난다. 이것은 로봇 후면에 설치된 2개의 수직추진기가 수직 하향으로 유동을 발생시킬 때, ROV 몸체 프레임에 유동이 직접 간섭을 받음으로써 추진력을 크게 잃어버리는 것으로 분석되었다. 수직추진기의 기울기와 직접적 간섭을 일으키는 프레임의 형상 변경이 주요 해결책으로 제안 되었다.

결국, 추진기 작동에 의해 발생되는 잠수정의 추진력 또는 모 멘트는 단순한 추진기 기하학적 배치에 따른 추력의 합력으로 산정해서는 오차가 클 수 있음을 확인하였다. 아울러, 추진기 작동에 의해 발생되는 유동의 원활한 흐름이 보장되도록 잠수 정 설계 과정에서 추진기 배치를 신중히 고려해야 한다.

\section{5. 결 론}

$\mathrm{ROV}$ 를 활용한 자율작업에 있어, 로봇이 대상물체까지 경로 를 생성하며 움직이고, 로봇팔이 물체까지 접근할 때, 팔의 운 동 및 외란 등에 의해 몸체가 흔들리지 않도록 자세를 유지하 는 운동제어기술 요구된다. 이것을 실현하기 위해, $\mathrm{ROV}$ 의 추진 기 특성을 비롯한 동특성 파라미터에 관한 정보를 정확하게 파 악하는 것이 중요하다. 

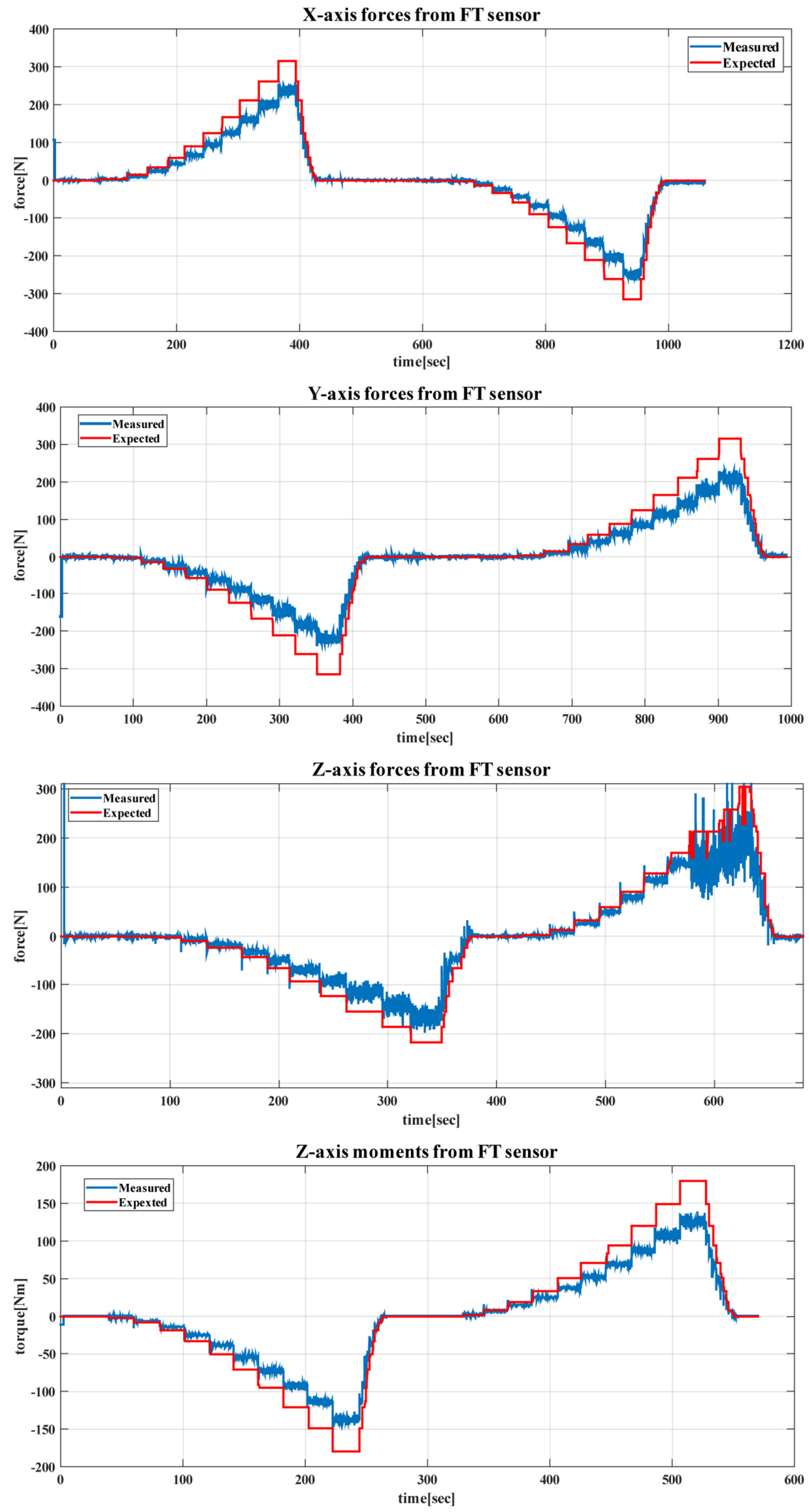

Fig. 9 Propulsion forces and Moments from F/T sensor 
본 연구에서는 수조 실험을 통해 ROV에 장착된 추진기의 개 별 추력 특성과 ROV 몸체에 장착된 상태에서 발생되는 추진력 및 모멘트를 직접 측정함으로써 추진 특성을 분석하고자 하였 다. 이를 위해, 먼저 1 축 로드셀이 장착된 추력 측정 장치를 제 작하고, 수조 실험을 통해 추진기별 입력-추력 관계식을 얻었다. 다음으로 6축 $\mathrm{F} / \mathrm{T}$ 센서를 $\mathrm{ROV}$ 몸체에 장착시킨 후, 추진기 작동 에 의해 ROV에 발생되는 추진력과 모멘트를 직접 측정하였다. 이론적으로 ROV 몸체 운동을 발생시키는 추진력 또는 모멘트 는 각 추진기에 의해 생성된 추력의 합력 성분과 일치해야 하 지만, 본 실험을 통해 얻어진 실측 결과는 최대 $30 \%$ 까지의 큰 차이를 가지는 것으로 확인되었다.

본 연구 결과는 KRISO AI-ROV의 구조 개선, 추진력 최적 추 력 분배, 그리고 ROV 동특성 파라미터 예측 및 제어기 설계 등 에 중요한 자료로 활용될 것이다.

\section{후 기}

본 연구는 선박해양플랜트연구소 주요사업 ‘수중 자율작업을 위한 3차원 물체인식 및 로봇-로봇팔 운동보상제어 기반기술 개발'로 수행된 연구결과입니다(PES3170).

\section{References}

Ait-Ahmed, N., Vonnet, M., Loron, L., Guibert, C., 2007. On Modeling of Marine Thrusters for Underwater Vehicles. Proceedings of $7^{\text {th }}$ IFAC Conference on Control Application in Marine Systems. 40(17), 211-216. https://doi.org/10.3182/ 20070919-3-HR-3904.00038

Christ, R.D., Werinli, R.L., 2007. The ROV Manual: A User Guide for Observation-Class Remotely Operated Vehicles. Elsevier.

Fossen, T.I., 1994. Guidance and Control of Ocean Vehicles. John Wiley \& Sons, England.

Giovanni, I., 1998. Modelling and Identification of Underwater
Robotic Systems. Ph.D Thesis, University of Genova, 1-149. Haugalokken, B.O.A., Jorgensen, E.K., Schjolberg, I., 2018. Experimental Validation of End-effector Stabilization for Underwater Vehicle-manipulator Systems in Subsea Operations. Robotics and Autonomous Systems, 109, 1-12. https://doi.org/ 10.1016/j.robot.2018.08.007

Healey, A.J., Rock, S.M., Cody, S., Miles, D., Brown, J.P., 1995. Toward an Improved Understanding of Thruster Dynamics for Underwater Vehicles. IEEE Journal of Oceanic Engineering. 20(4), 354-361. https://doi.org/10.1109/AUV.1994.518646

Mohan S., Kim J.H., 2015. Coordinated Motion Control in Task Space of an Autonomous Underwater Vehicle-manipulator System. Ocean Engineering, 104, 155-167. https://doi.org/ 10.1016/j.oceaneng.2015.05.011

Simetti, E., Casalino, G., Wanderlingh, F., Aicardi, M., 2018. Task Priority Control of Underwater Intervention Systems: Theory and Applications. Ocean Engineering, 164, 40-54. https://doi. org/10.1016/j.oceaneng.2018.06.026

Tsukamoto, C.L., Lee, W., Yuh, J., Choi, S.K., Lorentz, J., 1997. Comparison Study on Advanced Thruster Control of Underwater Robots. Proceedings of International Conference on Robotics and Automation, 1845-1850. https://doi.org/10.1109/ROBOT. 1997.619056

Yeu, T., Choi H.T., Lee, Y., Chae, J., Lee, Y., Kim, S.S., Park, S., Lee, T.H., 2019. Development of Robot Platform for Autonomous Underwater Intervention. Journal of Ocean Engineering and Technology, 33(2), 168-177. https://doi.org/ 10.26748/KSOE.2019.021

Yoerger, D.R., Cooke, J.G., Slotine, J.J.E., 1990. The Influence of Thruster Dynamics on Underwater Vehicle Behavior and Their Incorporation into Control System Design. IEEE Journal of Ocean Engineering, 15(3), 167-178. https://doi.org/10.1109/ 48.107145 